\title{
DETERMINANTS OF FARMERS DEMAND FOR SUBSIDIZED AGRICULTURAL INSURANCE IN POLAND
}

\author{
Agnieszka Kurdys-Kujawska ${ }^{1}$, assistant professor; \\ Agnieszka Sompolska-Rzechula ${ }^{2}$, assistant professor \\ ${ }^{1}$ Koszalin University of Technology, Faculty of Economics, Department of Finance, ${ }^{2}$ West Pomeranian University \\ of Technology Szczecin, Faculty of Economics, Department of Applied Mathematics in Economics.
}

Abstract. Concerns about food security, price volatility along with an increase in frequent unfavourable weather phenomena creates the necessity to make greater efforts to protect and stabilize agricultural income and production capacity. Undoubtedly, one of the main activities is to popularize and increase farmers' access to insurance. Nevertheless, the decision to purchase agricultural insurance depends to a large extent on the characteristics of the farm, as well as the farmers themselves. The purpose of this article is to identify factors and assess role they play affecting the likelihood of farmers purchasing subsidized agricultural insurance. Data were collected in the region of Central Pomerania using a questionnaire. Identification of factors affecting the probability of purchasing subsidized agricultural insurance was made using the logit regression model. The base for the model was a set of independent variables obtained and based on a survey conducted in 2012 amongst owners or managers of an agricultural holding. The analysis showed that the decision to purchase subsidized agricultural insurance depended on the number of people permanently employed on the farm and on the occurrence of damage in the past. The research presented results which suggest that the probability of purchasing subsidized agricultural insurance increased as the number of people permanently employed on the farm grows, and that it is more than eleven times higher in the case of units that in the past suffered damage caused by natural disasters.

Key words: demand for insurance, subsidized agricultural insurance, logit model. JEL code: Q14,G22, C38.

\section{Introduction}

Concerns about food security, price volatility and a frequent increase in unfavourable weather phenomena creates the need to make greater efforts to protect and stabilize agricultural income and production capacity. Undoubtedly, one of the main activities is to popularize and increase farmers' access to insurance. Insurance stabilizes farmers' income, helping them in the fight against the loss of crops due to unfavourable weather (Wang K. et al., 2015). They contribute to increasing the efficiency of allocating farm resources (Arias D., Covarrubias K., 2006) and strengthen the sustainable development of agricultural holdings (Kurdys-Kujawska A., 2016; Pawlowska-Tyszko J., Soliwoda M., 2017). Despite the significant role that insurance plays in agricultural activity, the level of itsuse in Poland is low. To increase the popularity of insurance, the Act on Agricultural Crops and Livestock Insurance was introduced in 2005. It assumed the use of premium subsidies for signing insurance contracts against the risk of occurrence of adverse events and their effects in agriculture. This Act has been amended many times in the past decade, which stemmedthe need to adapt national regulations to thosein the European Union among other reasons. Currently in Poland, the area of crops covered by insurance is at the level of approximately 3.5 million ha in relation to approximately 0.8 million ha before the introduction of the subsidy system. From year to year, both the area of insured crops and the number of insured farmers increased (www.gu.com.pl). As noted by J. Pawlowska-Tyszko et al. (2015), an increase in the popularity of insurance is correlated with the amount of contributions to premiums, which increased from approximately 9.86 million PLN to 164.4 million PLN. Despite the fourfold increase in the insured area of crops, the use of subsidized insurance is still low and is at the level of $20 \%$ of all agricultural land covered by direct payments (without grassland it is less than $10 \%$ ) (www.ppr.pl). Research aimed at identifying the factors affecting the probability of farmers 
purchasing subsidized agricultural insurance may contribute to determining the main reasons for the low level of their use. It is worth noting that the knowledge of factors affecting the probability of purchase of subsidized agricultural insurance is important in assessing the legitimacy and costeffectiveness of insurance programs based on public support (Goodwin B. K., Smith V. H., 1995). It can also play an important role in creating effective subsidy programs (Zhang R., Fan D., 2016) and enable policy makers to predict farmers' responses to any changes in an already existing system. In addition, the need to engage in research on identifying the determinants of subsidized agricultural insurance results from the growing debate on their importance in the process of adapting to the changing climatic conditions in agriculture. The aim of the study is to identify factors and assess role they play affecting the likelihood of farmers purchasing subsidized agricultural insurance.

\section{Factors determining the demand for subsidized agricultural insurance}

The tendency of farmers to use subsidized insurance is influenced by a range of different factors. These factors appear in literature and can be divided into three groups. The first relates to the specific characteristics of farmers (e.g. education, attitude to risk, non-agricultural sources of income), the second group consists of economic factors (e.g. insurance premium, income, debt level), whilst the third consists of factors related to specific features of the region in which the agricultural holding is located (e.g. terrain, soil quality, economic and social infrastructure) (Cabas J. H., Leiva A. J., Weersink A., 2008). Factors determining the participation of farmers in the system of subsidized insurance is the subject of consideration for many scientists. p. Barry et al. (2004) point out that farmers purchasing decisions in the matter of subsidized crop insurance are determined by the size of the farm, the structure of the land, the period of functioning, the level of indebtedness and the degree of exposure of the farm to income risk. M. A. Mohammed and G. F. Ortmann (2005) analyzing the factors affecting the likelihood of obtaining farm animal insurance by Eritrean farmers, showed that the farmer's education level has a positive effect on the probability of buying inventory insurance, whilst the negative effect can be created by factors such as the use of alternative risk management strategies (including diversification of production and undertaking investment activities outside the farm), the breeder's experience, farm location and poorly developed infrastructure, which increases transaction costs. R. Zhang and D. Fan (2016), when assessing the level of farmers' demand for crop insurance in China, prove that income, gender, education level, experience, premium size, a farmer's household size, farm area and previous experience have detrimental effect on the probability of using insurance protection. P.K.R. Dhanireddy and G. Frisvold (2012), examining the factors affecting the purchase of crop insurance and receiving aid payments by US farmers, cite evidence that the factors influencing the probability of participation in federal crop insurance programs include: age of the farmer, level of education, sales value, income from agricultural production and climatic conditions. B. K. Goodwin and R. M. Rejesus (2008) prove that diversification of production, larger share in total animal production and a higher loss ratio have a positive impact on the probability of farmers to use crop insurance, while a higher premium, income from non-agricultural sources and the amount and frequency of ad hoc assistance for disaster victims all have a negative effect. S. Ghazanfar et al. (2015), based surveys conducted amongst farmers in Pakistan, indicate that having credits or loans, the expected rate of return, farm income, farm area, the experience of damage and land ownership structure have a significant impact on farmers' willingness to participate in the crop 
insurance system. G. Santeramoin $(2015 ; 2016)$, analysed farms in Italy, and showed that farmers with higher education and larger farms are more likely to take advantage of insurance. On the other hand, older farmers using irrigation systems and diversifying their production are characterized by lower probability of taking out insurance. According to S. Makki and A. Somwar (1999), the factors determining the farmers' demand for crop insurance include the level of risk, insurance price, the amount of state subsidies, the expected amount of compensation, the availability of alternative insurance products and the nature of the insurance contract. M. G. Ginderai A. D. Spauldinga (2006) confirm the results of other authors, pointing out that in addition to weather hazards, the factor that significantly affects farmers' decisions about buying insurance is its price and the amount of state subsidies. Similarly, Enjolras et al. (2012) who when analysing crop insurance in France and Italy, along with factors that have a significant impact on farmers' insurance decisions mention farm size, crop diversification and insurance premiums. E. Sihem (2017) proves that apart from socio-economic factors (including insurance premium, subsidy amount, farm area, farmer's education level and risk related to yields), religious issues also determine the use of agricultural insurance in the countries of America and Europe. It is also worth noting the results obtained by Polish researchers. According to D. Walczak (2011), the probability of farmers benefiting from subsidized crop insurance is positively influenced by the area of the agricultural holding and sources of agricultural income. In turn, A. Wicka (2013) proves that the size of the farm, the share of plant production in sales and the level of income have a positive impact on the use of crop insurance.P. Sulewski and A. Kloczko-Gajewska (2014) indicate that the likelihood of purchasing subsidized insurance depends on the quality of soils, past losses, having credit obligations and having children. M. Kaczala (2015) proves that the location of the farm, the type of crops, the occurrence of damage events in the past, financing of previous damage from insurance, the size of the farm and arable land, the purpose of running the farm and soil class are also important. J. Pawlowska-Tyszko et al. (2016) state that factors influencing the farmers to purchase subsidized crop insurance may result from macroeconomic and sectoral conditions, includingthe psychological profile of the person running the farm. However, the most frequent reasons for the purchasing of subsidized crop insurance were the increasingly noticeable changes in the climate, i.e. hazards resulting from weather risk. As indicated by the example of research results from various authors, the issue of farmers' participation in the subsidized insurance system in agriculture is widely analysed. Taking into account the presented research results, factors which are most often mentioned by researchers are the following: area of the farm, the level of education of the farmer, the use of alternative risk management tools and the amount of the insurance premium.

\section{Materials and methods}

The study was conducted in the northern part of Poland in the region of Central Pomerania, which is a typically agricultural region. There is a prevalence of rye complex of very good, good and weak type. The share of soils in the very good wheat complex is small. The climate here is mild and humid, and the growing season is very long compared to other regions in Poland. This region is characterized by a high share of commodity farming with a predominance of animal production, and the traditional subsistence farming. The analysed units were the owners or managers of agricultural holdings. The research was carried out using a questionnaire survey in 2012. Answers were obtained based on the acceptance of participation in the study. 256 questionnaires were 
qualified for the study to estimate the likelihood of farmers benefiting from subsidized agricultural insurance, logistic regression was used. The logit model made it possible to describe the relationship between the dichotomous qualitative variable "use of subsidized agricultural insurance" $(Y)$ and the set of independent variables $\left(X_{1}, \ldots, X_{k}\right)$.

The logistic regression model enables investigating the influence exerted by many independent variables $X_{1}, \ldots, X_{k}$ on the dichotomous dependent variable $Y$. The values of the dependent variables are coded as follows: 1 - the distinguished value - possessing the feature, 0 - not possessing the feature. In the logit regression, the logistic function is used, having values from the range $(0 ; 1)$ and curve resembling the stretched $S$ letter, whose analytical form is as follows (Stanisz 2007):

$$
f(z)=\frac{e^{z}}{1+e^{z}}=\frac{1}{1+e^{-z}}, \quad z \in R
$$

The logistic regression model for the dichotomous variable $Y$ specifies the conditional probability of taking by this variable the distinguished value and it is expressed by the following dependence (Maddala 2001, Stanisz 2007):

$$
P\left(Y=1 / X_{1}, \ldots, X_{k}\right)=\frac{e^{\alpha_{0}+\alpha_{1} X_{1}+\ldots+\alpha_{k} X_{k}}}{1+e^{\alpha_{0}+\alpha_{1} X_{1}+\ldots+\alpha_{k} X_{k}}}
$$

where $\alpha_{0}, \alpha_{1}, \ldots, \alpha_{k}$ they are parameters of the model, $X_{1}, \ldots, X_{k}$ independent variables that may have both the qualitative and the quantitative character. The logistic regression model coefficients can be searched for with the maximum likelihood method (Dobosz 2004) or with the ordinary least squares method (Gruszczynski, Podgorska, 1996).

Due to the model (2) nonlinearity in relation to the independent variables and parameters, by finding the logarithm the logistic model is transformed into the linear model. For this purpose, the Odds Ratioconcept is introduced, which is the ratio of the probability of a given event occurrence to the probability that the said event shall not occur, that is:

$$
\frac{P\left(Y=1 / X_{1}, \ldots, X_{k}\right)}{1-P\left(Y=1 / X_{1}, \ldots, X_{k}\right)}=\frac{e^{\alpha_{0}+\alpha_{1} X_{1}+\ldots+\alpha_{k} X_{k}}}{1+e^{\alpha_{0}+\alpha_{1} X_{1}+\ldots+\alpha_{k} X_{k}}}: \frac{1}{1+e^{\alpha_{0}+\alpha_{1} X_{1}+\ldots+\alpha_{k} X_{k}}}=e^{\alpha_{0}+\alpha_{1} X_{1}+\ldots+\alpha_{k} X_{k}}
$$

So the Odds Ratioexpresses how many times the probability that a given event shall take place increases or decreases, if there shall occur a change of independent variable (at established values of independent variables). Natural logarithm of the Odds Ratiois linear in relation to independent variables and considering the model parameters, which facilitates estimation to a high degree. It is called the logit or the logit form of the logistic model, therefore (Stanisz 2007, Cramer 2003, Kleinbaum, Klein 2002):

$$
\operatorname{logit} P=\ln \frac{P\left(Y=1 / X_{1}, \ldots, X_{k}\right)}{1-P\left(Y=1 / X_{1}, \ldots, X_{k}\right)}=\alpha_{0}+\sum_{i=1}^{k} \alpha_{i} X_{i}
$$

The evaluation of the correctness of the estimated model can be carried out, counting correctly and mistakenly the classified cases (Table 1). 


\section{Correctness of classification of cases}

\begin{tabular}{|l|c|c|c|}
\hline \multirow{2}{*}{ Expected sizes } & \multicolumn{2}{|c|}{ Observed sizes } & \multirow{2}{*}{ Sum } \\
\cline { 2 - 3 } & $y_{i}=1$ & $y_{i}=0$ & $n_{1 \bullet}$ \\
\hline$\hat{y}_{i}=1$ & $n_{11}$ & $n_{12}$ & $n_{2 \bullet}$ \\
\hline$\hat{y}_{i}=0$ & $n_{21}$ & $n_{22}$ & $\mathrm{n}$ \\
\hline Sum & $n_{\bullet 1}$ & $n_{\bullet 2}$ & \\
\hline
\end{tabular}

\section{Source: the authors' elaboration on the basis of Dobosz 2004}

For evaluating the degree of the logistic regression model fitting to the empirical data, one can use the measure called count- $R^{2}$, which takes values from the range $\langle 0,1\rangle$, defined as follows (Maddala 2008):

$$
R_{\text {count }}^{2}=\frac{n_{11}+n_{22}}{n}
$$

The more the measure value is approximate to one, the better fit of the logistic model to empirical data of the investigated phenomenon is obtained, $R_{\text {count }}^{2}$ stands for the percentage of correctly classified cases. The model has turned out to be good in the prediction of the investigated phenomenon, when $R_{\text {count }}^{2}>50 \%$.It means that the classification based on the model is better than that being the random one.

The quality of the built up logistic regression model can be also evaluated using other measures e.g.: Hosmer-Lemeshow test (Hosmer et al. 1989, Hosmeret al. 2008) and AUC (Area Under the Curve) - area under the ROC curve (Receiver Operating Characteristic Curves). The ROC curve is formed by connecting the points in the cartesian coordinate system having the coordinates (sensitivity, 1-specificity). Sensitivity describes the ability to detect units having the distinguished characteristic. It is determined as follows:

$$
\text { sensitivity }=\frac{n_{11}}{n_{\bullet 1}}
$$

Specificitydescribes the ability to detect units not having the distinguished characteristic. It is determined according to the following formula:

$$
=\frac{n_{22}}{n_{\bullet 2}}
$$

Based on empirical research and the available database, variables were selected that could influence farmers' decisions to purchase subsidized agricultural insurance. A set of explanatory variables was used in the model, in which the use of subsidized agricultural insurance $(Y)$ was accepted as the response variable. Explanatory variables created a set of the following diagnostic features: the age of the farm manager (in years) $\left(X_{1}\right)$; the level of education of the farm manager (primary - 1, vocational - 2, secondary - 3, higher - 4) $\left(X_{2}\right)$; the number of permanent workers on the farm $\left(X_{3}\right)$; having a successoron the farm (no - 0, yes - 1) $\left(X_{4}\right)$; farm management period (in years) $\left(X_{5}\right)$; area ofagricultural land (in ha) $\left(X_{6}\right)$; area of own land (in ha) $\left(X_{7}\right)$; source of farmer's household income at the end of 2012 (from non-agricultural activity - 0, from agricultural activity - 
1) $\left(X_{8}\right)$; dominant soil class (class I - 1 , class II - 2 , class III - 3, class IV -4 , class V - 5 , class VI - 6) $\left(X_{9}\right)$; predominance of plant production (no - 0, yes - 1$)\left(X_{10}\right)$; predominance of animal production (no - 0, yes - 1) $\left(X_{11}\right)$; predominance of mixed production (no - 0, yes - 1$)\left(X_{12}\right)$; the number of fixed assets on the agricultural holding at the end of $2012\left(X_{13}\right)$; the amount of voluntary insurance premium (high - 0 , low -1) $\left(X_{14}\right)$; the number of natural disasters that occurred on the farm in 2004-2012 ( $\left.X_{15}\right)$; the level of farm's exposure to natural risk (scale from 1 to 5 , where: 1 - low, 5 - high) $\left(X_{16}\right)$; the occurrence of damage to an agricultural holding (no - 0 , yes -1$)\left(X_{17}\right)$; the amount of compensation received by the farmer in the years 2004-2012 $\left(X_{18}\right)$.

\section{Research results and discussion}

This section consists of two parts. The first one contains the characteristics of the surveyed farms from the Central Pomerania region. The second one presents the results of the logit regression analysis. In the years 2005-2012, from $3.9 \%$ to $7.03 \%$ of the surveyed farmers participated in the system of subsidized insurance, the subsidized crop insurance in particular. The main motive for the purchase of subsidized crop insurance was concern about the future of the agricultural holding. In the majority of farms ( $83 \%)$, farmers have had previous experience relating to the loss of crops as a result of unfavourable weather phenomena. Compensation was paid to the majority of them, and its sum covered 30-40\% of the losses incurred. The average age of the farm owner was 48. The largest group were respondents with secondary education (56 \%), followed by vocational ( $22 \%$ ) and primary ( $16 \%$ ) education, while $6 \%$ had post-secondary education. In the analysed group of farms, none of the respondents had higher education. The farmers were characterized by extensive experience in running a farm, of an average of 19 years. The majority were farms in which two people were employed permanently - usually the owner's relatives, i.e. wife or children. Four people were employed seasonally on average, with the maximum of six. Over $70 \%$ of farmers declared having a successor who could take over the farm in the future. Agricultural activity was the main source of income in all farms. The average area of agricultural land was 68 ha. $50 \%$ of the surveyed farmers specialized in field crops, and the other $50 \%$ conducted mixed production, in which herbivorous animals were predominant. Most of the farms contained arable soils belonging to class IVa and IVb. These are medium-quality superior and inferior soils. Medium yields can be obtained from them, which depend to a large extent on the amount and distribution of atmospheric precipitation, especially during the growing season. Cereal and potato cultivation prevailed in the analysed farms, which was mainly conditioned by the quality of soils. According to the farm owners, their agricultural activity is exposed to the occurrence of drought, freezing and spring frosts to the largest extent, and to a minimal extent to hail, flood and hurricane. In order to find the best combination of variables significantly affecting the purchase of subsidized agricultural insurance, formal selection of variables was made by means of backwards stepwise regression. The obtained results indicate that two factors influence the purchase of subsidized insurance, i.e. the number of people employed permanently on the farm and the occurrence of damage to the farm in the past. These features are poorly correlated with each other and at the same time strongly correlated with other variables eliminated from the set of potential diagnostic features. Evaluation of the parameters of the estimated logit model is presented in Table 2. 
Evaluation of logit model parameters

\begin{tabular}{|l|l|c|c|c|}
\hline \multirow{2}{*}{ Variable } & \multicolumn{1}{|c|}{ Variable name } & $\begin{array}{c}\text { Parameter } \\
\text { evaluation }\end{array}$ & p-value & Odds ratio \\
\cline { 2 - 5 } & Constant & $\mathbf{- 6 . 1 6 8 0 2}$ & - & - \\
\hline X3 & number of people employed permanently on the farm & 0.96123 & 0.00010 & 2.61492 \\
\hline $\mathbf{X 1 7}$ & occurrence of damage to the farm in the past & 2.45210 & 0.00073 & 11.61267 \\
\hline
\end{tabular}

Source: author's calculations

The estimated logistic model takes the following form:

$$
\hat{p}=P(y=1)=\frac{e^{-6.16802+0.96123 x_{3}+0.13481 x_{17}}}{1+e^{-6.16802+0.96123 x_{3}+0.13481 x_{17}}} .
$$

After conversion, the model can be represented as follows (average estimation errors in brackets):

$$
\operatorname{logit} \hat{p}=-\underset{(1.00546)}{6.16802+0.24725)}+0.96123 x_{3}+\underset{(0.726154)}{0.13481} x_{17}
$$

The first important factor that positively affects farmers in the region of Central Pomerania having subsidized insurance is the number of people permanently employed in the agricultural holding. Interpreting the odds ratios at the $i$-th variable (assuming that the remaining variables included in the model will remain unchanged), it can be concluded that if the number of people employed on a permanent basis increases by one person, then the probability of taking advantage of subsidized insurance will increase 2.6 times. This may mean that theneed for stabilizing farm income is greaterwhen more people are employed on the farm(mainly relatives of the farm manager) permanently and full-time. In addition, the higher number of people permanently employed in an agricultural holding may result from a larger scale of commodity production, or more labour-intensive directions of production, mainly to strengthen or maintain market position. Therefore, it can be assumed that farmers from farms focused on market production also show greater propensity to have insurance. Another factor is the occurrence of damage to the agricultural holding. In units which incurred damage caused by adverse weather conditions in the past, the probability of using subsidized insurance is more than eleven times higher than for entities where such damage did not occur. This means that previous experiences of loss or reduction of income resulting from damage to agricultural production may result in higher insurance awareness and thus increase the likelihood of benefiting from subsidized insurance. Table 3 presents the accuracy of farm classification based on the designated model.

\begin{tabular}{|c|c|c|c|}
\hline \multirow{2}{*}{$\begin{array}{l}\text { Classification of holdings } \\
\text { based on the logit model }\end{array}$} & \multicolumn{2}{|c|}{ Actual classification of the farm } & \multirow{2}{*}{$\begin{array}{c}\text { Overall } \\
\text { accuracy of the } \\
\text { classification }\end{array}$} \\
\hline & $y_{i}=1$ & $y_{i}=0$ & \\
\hline$\hat{y}_{i}=1$ & 2 & 2 & \multirow{3}{*}{$92.97 \%$} \\
\hline$\hat{y}_{i}=0$ & 16 & 236 & \\
\hline Sensitivity, specificity & $11.11 \%$ & $99.16 \%$ & \\
\hline
\end{tabular}

Accuracy of the logit model classification

Source: author's calculations 
Classification accuracy was also assessed using an $R^{2}$ count coefficient, whose value amounted to $92.19 \%$, which indicates that the classification based on the model is much better than a random one (Figure 1).

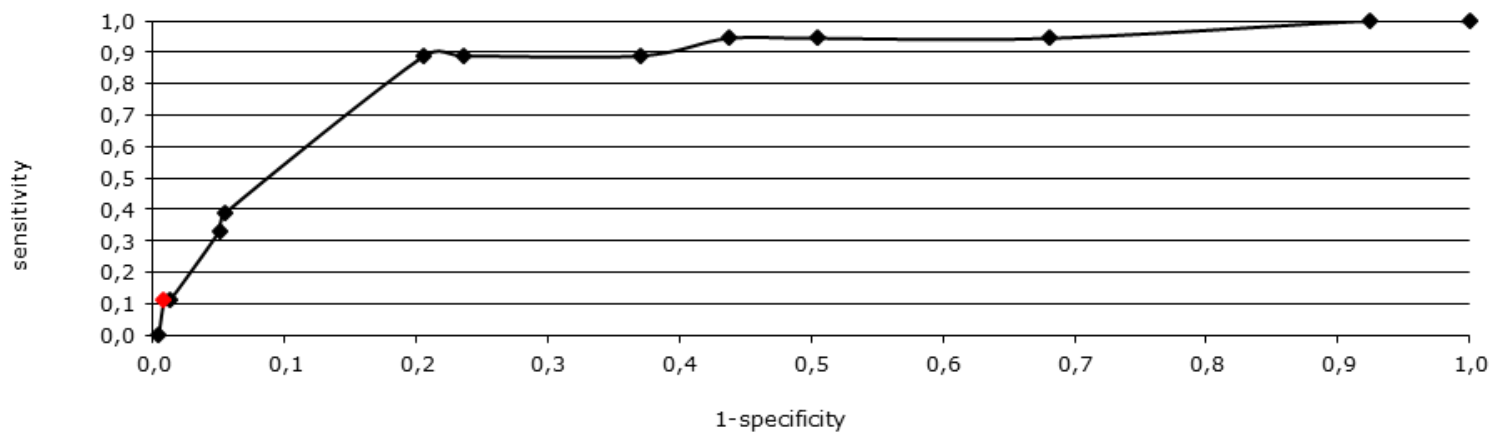

Source: author's calculations

Fig. 1.The ROC curve for model

The results of the Hosmer-Lemen test indicates a lack of significant differences between the empirical and theoretical numbers that result from the estimated logistic regression models $\left(\chi^{2}=4.7, p=0.3264\right.$ ). The area under the ROC curve is 0.85 and is significantly higher than 0.5 (at a significance level greater than 0.000001 ). The cut-off point for the model is equal to 0.5322 . The classification determined on the basis of this cut-off point gives almost $93 \%$ of correctly classified cases, of which $11.11 \%$ for "yes" and $99.16 \%$ for "no".

\section{Conclusions}

This article presents a logistic regression model which enabled determination of factors influencing the probability of purchasing subsidized agricultural insurance by farmers from the Central Pomerania region. Econometric results indicate that the model is well-matched and statistically significant. It is characterized by good quality, which is proved by the measures used to assess the quality of the model, i.e.: the $R^{2}$ count coefficient, Hosmer-Lemenshow test and ROC curve and its components (area under the curve and cut-off point). In addition, the model has a high accuracy of classification at $92.97 \%$. The analysis included eighteen variables. It was found that two variables have a significant positive impact on the probability of purchasing subsidized agricultural insurance. These are the number of people permanently employed in the agricultural holding and past experiences of damage to agricultural production caused by unfavourable weather conditions. The presented research results suggest that the probability of purchasing subsidized agricultural insurance by farmers from the Central Pomerania region increases with the number of people permanently employed on the farm; and the chances of farmers participating in the system of subsidized agricultural insurance is over eleven times higher in the case of units with past experience of damage caused by unfavourable atmospheric phenomena. To sum up, the obtained results show that the system of subsidized insurance is mainly utilized by farmers for whom the farm is a workplace, therefore it is a source of income for the farmer's family, and which is characterized by a high level of exposure to natural risk. 


\section{Bibliography}

1. Arias, D., Covarrubias, K. (2006). Agricultural; Insurance in Mesoamerica: An Opportunity to Deepen Rural Financial Markets. Inter-American Development Bank, Washington D.C.

2. Barry, P., Ellinger, P., Schnitkey, G., Sherrick, B. (2004). Factors Influencing Farmers' Crop Insurance Decisions. American Journal Agriculture Economics, 1.

3. Cabas, J.H., Leiva, A.J., Weersink, A. (2008). Modelling Exit and Entry of Farmers in a Crop Insurance Program. Agricultural and Resource Economics Review, 37/1.

4. Cramer, J. S. (2003). Logit Models from Economics and Other Fields. Cambridge University Press, Cambridge.

5. Dhanireddy, P.K.R., Frisvold, G. (2012). Disaster Assistance and Crop Insurance Participation in US. Agricultural \& Applied Economics Association's Annual Meeting, Seattle, Washington.

6. Dobosz, M. (2004). Wspomagana komputerowo statystyczna analiza wynikow badan(Computerassistedstatisticalanalysis of test results). Akademicka Oficyna Wydawnicza EXIT. Warszawa, p. 260.

7. Enjolras, G., Capitanio, F., Adinolfi, F. (2012). The Demand for Crop Insurance: Combined Approaches for France and Italy. Agricultural Economics Review, 1.

8. Ghazanfar, S., Qi Wen, Z., Abdullah, M., Ahmad, J., Khan, I. (2015). Farmers' Willingness to Pay For Crop Insurance In Pakistan. Journal of Business, Economics \& Finance, 4:2.

9. Ginder, M. G., Spaulding, A. D. (2006). Factors Affecting Crop Insurance Purchase Decisions in Northern Illinois. Selected paper prepared for presentation at the American Agricultural Economics Association Annual Meetings, Long Beach, California.

10. Goodwin, B.K., Rejesus, R.M. (2008). Safety Nets or Trampolines? Federal Crop Insurance, Disaster Assistance, and the Farm Bill. Journal of Agricultural and Applied Economics, 40.

11. Goodwin, B.K., Smith, V.H. (1995). The Economics of Crop Insurance and Disaster Aid. American Enterprise Institute for Public Policy Research, Washington D.C.

12. Gruszczynski, M. (ed), Podgorska, M. (ed). (1996). Ekonometria (Econometrics). Oficyna Wydawnicza Szkoly Glownej Handlowej, Warszawa, pp. 139-141.

13. Hosmer, D. W., Lemenshow, S., May S. (2008). Applied Survival Analysis: Regression Modeling of Time to Event Data. WILEY-BLACKWELL.

14. Hosmer, Jr D. W., Lemenshow S. (1989). Applied Logistic Regression. John Wiley, New York.

15. http://www.gu.com.pl/ Concordia (28 kwietnia 2015)

16. http://www.ppr.pl/wiadomosci/aktualnosci/polska-wies-nadal-nieubezpieczona-176867 (28 kwietnia 2015)

17. Kaczala, M. (2015). Zawieranie umow ubezpieczenia upra w przez gospodarstwa indywidualne (Conclusion of crop insurance contract by indiwidua farms). [in:] Kaczala, M. Rojewski, K. (ed.), Ubezpieczenia produkcji roslinnej $w$ Polsce (Crop Insurance in Poland). Poltext, Warszawa.

18. Kaczala, M., Wisniewska, D. (2015). Risks in the Farms in Poland and their Financing - Research Findings. Research Papers of Wroclaw University of Economics, Volume 381.

19. Kleinbaum, D. G., Klein M. (2002). Logistic Regression. Springer, New York.

20. Kumar, R., Indrayan, A. (2011). Receiver Operating Characteristic (ROC) Curve for Medical Researchers. Indian Pediatrics, Volume 48.

21. Kurdys-Kujawska, A. (2016). Ubezpieczenia gospodarcze jako czynnik zapewniajacy zrównoważony rozwoj gospodarstw rolnych (Business insurances as a factor to ensuresustainableeconomic development of farms). Research Papers of Wroclaw University of Economics, 436, Wroclaw, pp. 154-173.

22. Maddala, G. S. (2008). Introduction to Econometrics. Third Edition. John Wiley \& Sons.

23. Makki, S.S., Somwaru, A. (2005). Demand for Yield and Revenue Insurance: Factoring in Risk, Income and Cost. Agricultural Outlook, Economic Research Service, U.S. Department of Agriculture.

24. Mohammed, M.A., Ortmann G.F. (2005). Factors Influencing Adoption of Livestock Insurance by Commercial Dairy Farmers in Three Zobatat of Eritrea. Agrekon, Volume 44, 2.

25. Mozdzioch, M., Ploch, A. (2010). Zmiany klimatyczne a ubezpieczenia upraw rolnych (Climatic changes and crop insurance). Wiadomosci ubezpieczeniowe, 3.

26. Pawlowska-Tyszko, J. (ed.), Soliwoda, M., Herda-Kopanska, J., Gorzelak, A. (2016). Instrumenty zarzadzaniaryzykiem w rolnictwie - rozwiazaniakrajoweimiedzynarodowe (Instruments of risk management in agriculture - national and internationalsolutions), IAFE-NRI, Warsaw.

27. Pawlowska-Tyszko, J. (ed.), Soliwoda, M., Pienkowska-Kamieniecka, S., Walczak D. (2015). Stan obecnyiperspektywyrozwojusystemupodatkowegoiubezpieczeniowegopolskiegorolnictwa (Current status and prospects for the development of the tax and insurance system of Polish agriculture), IAFE-NRI, Warsaw.

28. Pawlowska-Tyszko, J., Soliwoda M. (2017). Ubezpieczenia rolne a zrownowazenie ekonomiczne $i$ finansowe gospodarstw rolnych (Agricultural insurance vs. Economic and financial sustainability of farms). Research Papers of Wroclaw University of Economics, 478, pp. 337-347.

29. Santeramo, F.G., Farm-level Decisions and Turnover in Italian Crop Insurance Market, https://agecon.ncsu.edu/wp-content/uploads/2015/10/Santeramo_WP_NCSU_2015.pdf.(28 April 2015)

30. Santeramo, F.G., Goodwin, B. K., Adinol, F., Capitanio, F. (2016). Farmer Participation, Entry and Exit decisions in the Italian Crop Insurance Program. Journal of Agricultural Economics, 67(3). 
31. Sihem, E. (2017). Economic and Socio-cultural Determinants of Agricultural Insurance Demand across Countries. Journal of the Saudi Society of Agricultural Sciences. (https://doi.org/10.1016/j.jssas.2017.04.004.)

32. Stanisz, A. (2007). Przystepny kurs z zastosowaniem Statistica PL na przykladach z medycyny (An affordable course using Statistica PL on medical examples). Statsoft, Volume 3, Krakow.

33. Sulewski, P., Kloczko-Gajewska, A. (2014). Determinants of Taking Out Insurance Against Losses in Agricultural Production in Poland. Roczniki Naukowe Ekonomii Rolnictwa i Rozwoju Obszarow Wiejskich, Volume 101(4).

34. Walczak, D. (2011). Uwarunkowania funkcjonowania system zabezpieczenia społecznego rolnikow w Polsce (Conditions for the functioning of farmers' social security system in Poland). Dom Organizatora, Torun.

35. Wang, K., Zhang, Q., Kimura, S., Akter, S. (2015). In the Crop Insurance Program Effective in China? Evidence from Farmers Analysis in Five Provinces. Journal of Integrative Agriculture, Volume 14, Issue 10, pp. 2109-2120.

36. Wicka A. (ed.) (2013). Czynniki i mozliwosci ograniczania ryzyka w produkcji roslinnej poprzez ubezpieczenia (Factors and possibilities of risk reduction in crop production through insurance). Wydawnictwo Szkoly Glownej Gospodarstwa Wiejskiego, Warszawa.

37. Zhang R., Fan D. (2016). Evaluating Farm-Level Crop Insurance Demand in China: A Double-Bounded Dichotomous Approach. Journal of Agricultural Science, Volume 8, 3.

38. Zweig M.H., Campbell G. (1993). Receiver-operating Characteristic (ROC) Plots: a Fundamental Evaluation Tool in Clinical Medicine. Clinical Chemistry, 39. 